\title{
Exploring High School Students' Cognitive Structures for Energy Concept Through Word Association Test
}

\author{
Ömer Türksever ${ }^{1}$ \\ ${ }^{1}$ Faculty of Education, Yozgat Bozok University, Yozgat, Turkey \\ Correspondence: Ömer Türksever, Atatürk Yolu 7. Km, Erdoğan Akdağ Kampüsü, Eğitim Fakültesi, 66000 \\ Merkez/Yozgat, Turkey.
}

Received: May 13, 2021

doi:10.5539/ies.v14n9p58
Accepted: June 18, $2021 \quad$ Online Published: August 25, 2021

URL: https://doi.org/10.5539/ies.v14n9p58

\begin{abstract}
This research, which was conducted in order to reveal the cognitive structures of high school students regarding the concept of energy through the word association test, was designed in a survey model. Word association test was used as a data collection tool. After the necessary information was given to the students, they were given three minutes and they were asked to write the first words that came to mind about the key concept. The study group of the research consists of 202 students studying in a high school in the province of Malatya in the 2019-2020 academic year. 58 of these students are $9^{\text {th }}$ grade, 46 are 10th grade, 45 are $11^{\text {th }}$ grade and 53 are $12^{\text {th }}$ grade. While choosing the study group of the research, one of the purposeful sampling types was chosen based on easily accessible situation sampling. The words obtained related to the concept of energy are tabulated using Microsoft office excel program. The cut-off points of the tables, which were examined in detail and repeated words were taken into account, were determined. Concept networks were created in line with the determined cut-off points. In the research, 189 different words were produced for the concept of energy by high school students. While 114 of these words were not included in the analysis because they had 4 or less frequencies, 75 words were included in the analysis. Among the words included in the analysis, the most repeated word in the 9th grade was "petrol" ( $\mathrm{f}=30$ ), the most repeated word in the 10th grade was "fossil fuel" (24), the most repeated word in the 11th grade "electricity" (19), the most repeated word in the $12^{\text {th }}$ grade was found to be "potential" (28). In the comparison between the classes, a difference in quantity and quality is observed. It has been observed that as the grade level increases, the quality of the answers given increases.
\end{abstract}

Keywords: word association test, cognitive structure, energy

\section{Introduction}

In Turkish Language Association [TDK] dictionary (2005), energy is described as power which is in an object and comes out as heat and light. A great attention has been paid to energy since the humankind has begun to live on the Earth due to the fact that people require energy to survive and make production. Every system and living being need energy to perform and maintain its life (Dönmez Usta, Karsl1, \& Durukan, 2016). In this regard, energy is essential for both living and non-living beings (Aladağ, Tapur, \& Duran, 2018). People always need energy to sustain their life and energy has been one of the indispensable sources of countries throughout the history. When people choose a place to live on the Earth, it's important for them to be close to the energy sources (Aydın, 2010). As a basic input in production, energy is a necessary element for the rise of the welfare level of societies and is used in almost every field in daily life (Koç \& Kaya, 2015). Energy, in addition to being the most important necessity of a person in daily life, is very crucial for the development of countries, especially for economic development. Moreover, the economic, cultural and scientific rankings of countries are measured by the amount of energy they produce and use (Atılgan, 2000).

Energy sources are generally classified regarding their usage and convertibility. On the basis of their usage, it can be classified as renewable and non-renewable, furthermore, on the basis of convertibility it can be classified as primary and secondary energy sources (Karabulut, 2000; Koç \& Kaya, 2015). Lignite, coal, asphaltite, oil shale, crude oil, natural gas, uranium and thorium are kinds of fossil resource reserves and hydraulic energy, geothermal energy, solar energy, wind energy, and biomass energy are the potential renewable sources (Atılgan, 2000; Doğanay \& Coşkun, 2018). While the primary energy sources are plant and animal-originated fossils (Bilginoğlu, 1991), secondary energy sources consist of electricity, nuclear, solar, geothermal, wind, marine and biomass 
energy. These resources can be named renewable energy as well (Uslu, 2004).

In history, the need for energy and energy resources has differed depending on the trends of the period. Therefore, countries fought against each other and made treaties with different nations to obtain energy sources and to have authority over energy trade and energy transport routes (Pamir, 2003). After the Second World War, coal, which was considered an important energy source of its time, had influence on the states coming together and laying the foundations of the European Union (Akbulut, 2008).

Energy sources have an important place in Turkey, as in the world. In recent years, Turkey has become a country that is rapidly industrializing, urbanizing, increasing its population and competing with the countries of the world. For those reasons, ensuring energy diversity by producing energy from different sources, creating a competitive energy sector and using alternative energy sources have been a requirement for Turkey to meet its growing energy demand (Yıldırım \& Örnek, 2007). Turkey's economy has been developing quite rapidly since 1980. Despite the limited domestic resources available, the demand for primary and secondary energy is growing rapidly due to industrialization efforts. The main energy sources of our country are hydraulics and lignite. Turkey has no oil and gas reserves. A significant amount of them are imported (Haskök, 2005). Importing these products, which are important for the country, also leads to external dependence.

As a result of the developments in science and technology along with industrialization and urbanization, the scarce sources of the world are rapidly depleting and the demand for energy is increasing (Dikmenli, Öztürk Demirbaş, \& Gafa, 2019; Koç \& Kaya, 2015). In addition, the rapidly growing world population brings many problems as well. One of these problems is the lack of available energy resources (Geçit \& Yangın, 2012). Providing and using energy at an adequate level and not threatening environmental values are the most important problems of societies (Çukurçayır \& Sağır, 2008).

Countries around the world have to look for alternative energy sources in order to solve the problems that arise due to the growing population. In addition to meeting people's needs, some of these resources pose many environmental problems. Therefore, upon determining energy policies, countries should aim to use energy types that can best meet energy needs and do minimal or no harm to the environment (Geçit \& Yangın, 2012).

The energy consumption rate in the world is 300 thousand times higher than the formation rate of fossil fuels. In other words, fossil fuels formed in a thousand years are consumed in one day (Yılmaz, İlbaş, \& Su, 2003). Predictions about the remaining of fossil fuels in the world suggest that the future will not be very bright. Accordingly, it is estimated that oil will run out in 2050, natural gas in 2070 and coal in 2150 (Kantemir, 2003).

Depletion of fossil fuel reserves and failure to meet increasing energy demand cannot be avoided (Önder, 2001). As a result of the growing demand for energy need, the trend towards renewable energy sources is increasing all over the world and in our country as well. This is due to the fact that renewable energy has a greater advantage over fossil fuels and does not pollute the environment and constantly renew itself (Ülgen \& Hepbaşl1, 2002). Considering the rates of use all over the world, it is known that renewable energy sources have not become widespread enough at the point of replacing fossil fuels yet (Çolak, Kaymakçı, \& Akpınar, 2015). The reasons why the renewable energy sources have not become so widespread are because of the high cost of initial installation, lack of permanency, low efficiency, and inability to store the generated energy (Akova, 2008). It is believed that the permanent use of renewable energy could be possible with technologies that allow more efficient and more economical methods in the future, as well as the progress achieved in renewable energy studies (Şen, 2009).

Countries have been trying to find out solutions both to meet the growing need and to prevent environmental damage. Therefore, the use of renewable energy is becoming increasingly common, especially in developed countries, and the use of renewable energy is regarded as a kind of development indicator (Çolak, Kaymakçı, \& Akpınar, 2015). In general, countries' expectations for renewable energy use can be expressed as meeting the need for energy to some extent, reducing the dependence on fossil fuels and reducing polluting gases released into the atmosphere (Akova, 2008).

The use of renewable energy sources is vital to ensure the future of all mankind (Keleş \& Hamamc1, 2002). In terms of renewable energy sources, Turkey has a significant potential and the use of renewable energy sources is increasing gradually (Kaygusuz, 1999). Renewable energy sources of Turkey are solar, wind and geothermal energy. Furthermore, boron mines in Central Anatolia and the accumulated hydrogen potential beneath the Black Sea can be considered as other renewable energy sources of our country (Ülgen \& Hepbaşl1, 2002). Renewable energy sources can be regarded as the use of permanent energy flows without disrupting quantitative and qualitative characteristics or sources of energy that can keep existing the next day, in the course of nature's own evolution. Solar, water, biogas, biomass, wind, hydrogen, geothermal energy and sea currents are some example of renewable energy sources (Üstün, Apaydın, Başaran-Filik, \& Kurban, 2009). 
It should be taken into account that the environmental problems that people encounter, affect each individual one by one. This point of view suggests that students should be educated regarding the necessary information about energy. As the concept of energy contains a large framework depending on daily use, students sometimes have problems in learning concepts and fall into misconceptions. Some methods and techniques are used to determine misconceptions (Ercan, Taşdere, \& Ercan, 2010). One of these methods and techniques is the word association test.

Word association is a method used to reveal the relationships that people create among concepts (Kurtaslan, Aydin \& Özer, 2018). This method is practiced in order to "analyze the cognitive structure of students and the inter-concept relations-information network-in this structure" (Kurtaslan, Aydın, \& Özer, 2018). It is a technique used to determine the cognitive structure of students and the inter-concept connections in this structure. Moreover, it is practiced to find out whether long-term inter-concept relationships in memory are sufficient or meaningful (Kılıçavan \& Kalenderoğlu, 2018).

The aim of this research is to determine the cognitive structures of high school students towards the energy concept by means of the word association test. In the extant literature, various studies were carried out by conducting the word association test (Bahar \& Özatl1, 2003; Bahar, Johnstone, \& Sutcliffe, 1999; Cardellini \& Bahar, 2000; Cachapuz \& Maskill, 1987; Çiftçi, 2009; Deveci, Çengelci Köse, \& Gürdoğan Bayır, 2014; Ercan, Taşdere, \& Ercan, 2010; Gough, 1976; Johnstone \& Moynihan, 1985; Kaya \& Akış, 2015; Şimşek, 2013; Tokcan \& Yiter, 2017; Yel, Çetin, \& İnel, 2019). In addition, various studies have been conducted on the concept of energy in the literature (Akbulut, 2008; Aladağ, Tapur, \& Duran, 2018; Amador Amador, Carbonero Rosales, \& Jarquin Cabrera, 2021; Atılgan, 2000; Ay \& Tokcan, 2019; Aydın, 2010; Bilginoğlu, 1991; Çolak, Kaymakçı, \& Akpınar, 2015; Çukurçayır \& Sağır, 2008; Dikmenli, Öztürk Demirbaş, \& Gafa, 2019; Haskök, 2005; Kantemir, 2003; Kar, 2021; Kaygusuz, 1999; Koç \& Kaya, 2015; Önder, 2001; Pamir, 2002; Tokcan, 2017; Tokcan \& Topkaya, 2018; Uslu, 2004; Yıldırım \& Örnek, 2007; Yel \& Çetin, 2020). However, there are no similar studies conducted on the concept of energy at high school level. As the concept of "energy" is an important concept at high school level, this study aims to fulfill this gap.

\section{Method}

\subsection{Research Design}

This research aims to determine the cognitive structures of high school students regarding the concept of "energy". It was conducted using the survey design model, which is a research approach that aims to describe a situation that exists in the past or present as how it is in reality (Karasar, 2014).

\subsection{Participants}

Participants of this research are 202 students studying at a public high school in Malatya province in the 2019 2020 academic year. 58 of these students are $9^{\text {th }}$ grade, 46 of them are $10^{\text {th }}$ grade, 45 of them are $11^{\text {th }}$ grade and 53 of them are $12^{\text {th }}$ grade. In selection of the participants, convenient sampling was preferred because this sampling enables researcher to choose a sample that is readily available in some non-random way. Also, it allows researcher to collect data more quickly and in a practical way (Yıldırım \& Şimşek, 2016).

\subsection{Data Collection Tool}

In this research, WAT (Word Association Test) was used as a data collection tool, which aimed to determine the cognitive structures of high school students related to the concept of "energy". WAT consisted of two dimensions; on the first page, there are explanations about the WAT and a WAT sample, which comprised the first dimension of the research and on the second page, there is a WAT worksheet for the energy concept, which comprised the second dimension of the research.

\subsection{Collecting Data}

At the beginning of the data collection, the participants were informed about the data collection tool and process. Then the participants went over the first dimension of the WAT and then they are required to give their response in three minutes. Students were asked to write the first word that comes to their mind related to the key concept.

\subsection{Analyzing the Data}

The words obtained about the concept of energy are presented in tables using the Microsoft Office Excel program. Cut-off points of the tables were determined by considering the repeated words in detail. As a result of the examination and approval of the three experts from the field, cut-off points were decided regarding the responses and frequencies as 15 and above, range between 10-14 and range between 5 and 9. Then, concept networks were created in line with these cut-off points. 


\section{Findings}

In the following part, data obtained from the research findings were displayed in tables and presented as conceptual networks. The words uttered for the energy concept were presented in a separate table for each grade level, and then concept networks are created to display all grades together according to the specified cut-off points.

Table $1.9^{\text {th }}$ grade students' responses related to energy and their frequency values

\begin{tabular}{cccccc}
\hline Code & Response & f & Code & Response & f \\
\hline 1 & Oil & 30 & 12 & Electricity & \\
2 & Natural gas & 24 & 13 & Movement & 9 \\
3 & Coal & 23 & 14 & geothermal & 8 \\
4 & Heat & 19 & 15 & Saving & 7 \\
5 & Fossil fuel & 17 & 16 & Battery & \\
6 & Sun & & 17 & Sport & 6 \\
7 & Wave & & 18 & Power & \\
8 & Water & 14 & 19 & Physics & \\
9 & Wind & 11 & 20 & Power plant & 5 \\
10 & Renewable & & 21 & Heater & \\
11 & Technology & 10 & 22 & Others & 50 \\
\hline
\end{tabular}

Responses with frequencies of four and less than four are collected under the other option in the table. Responses to others are as following; heat, potential, light, transformation, voice, joule, nuclear, solar panels, Alper Erözen (pop singer), fan, synergy, clock, muscle, motor, plane, technology, production, Science class, produce, science, technician, importance, item, ability.

The $9^{\text {th }}$ grade students generated 46 different words related to energy. 25 of these words are not included in the table and concept network, as they fell outside the specified cut-off points. The words were listed below the table. That is, the words uttered fewer than four times were excluded from the analysis. Considering the $9^{\text {th }}$ grade students' words related to energy, 21 words were included in the analysis and the mostly articulated word was "oil" ( $\mathrm{f}=30)$.

Table 2. 10th grade students' responses related to energy and their frequency values

\begin{tabular}{cccccc}
\hline Code & Response & f & Code & Response & f \\
\hline 1 & Fossil fuel & 24 & 11 & Potential & 7 \\
2 & Coal & 19 & 12 & Voice & 6 \\
3 & Oil & & 13 & Non-renewable & \\
4 & Renewable & 16 & 14 & Productivity & \\
5 & Natural gas & 13 & 15 & Improvement & \\
6 & Sun & 12 & 16 & Battery & \\
7 & Kinetics & 10 & 17 & Water & 5 \\
8 & Wind & 9 & 18 & Dam & \\
9 & Geothermal & & 19 & Others & 39 \\
10 & Heat & 8 & & & \\
\hline
\end{tabular}

Responses with frequencies of four and less than four are collected under the other option in the table. Responses to others are as following; technology, light, central heating, fire, soil, forest, magnetics, heat, Alper Erözen (pop singer), wave, science class, force, happiness, wood, motor, battery, light, computer, redbull, nuclear, robot, synergy.

The $10^{\text {th }}$ grade students generated 41 different words related to energy. 23 of these words are not included in the table and concept network, as they fell outside the specified cut-off points. The words were listed below the table. That is, the words uttered fewer than four times were excluded from the analysis. Considering the $10^{\text {th }}$ grade students' words related to energy, 18 words were included in the analysis and the mostly articulated word was "fossil fuels" ( $\mathrm{f}=24)$. 
Table $3.11^{\text {th }}$ grade students' responses related to energy and their frequency values

\begin{tabular}{cccccc}
\hline Code & Response & $\mathrm{f}$ & Code & Response & $\mathrm{f}$ \\
\hline 1 & Electricity & 19 & 10 & Wind & 9 \\
2 & Oil & & 11 & Natural gas & 8 \\
3 & Coal & 16 & 12 & Mechanics & 7 \\
4 & Potential & 15 & 13 & Dam & \\
5 & Water & & 14 & Heat & \\
6 & Kinetics & & 15 & Voice & 6 \\
7 & Nuclear & 13 & 16 & Geothermal & 6 \\
8 & Bio-fuel & 12 & 17 & Renewable & 5 \\
9 & Sun & 10 & 18 & Other & 46 \\
\hline
\end{tabular}

Responses with frequencies of four and less than four are collected under the other option in the table. Responses to others are as following; light, chemical, internet, non-renewable, wave, air, recycling, physics, heat, joule, fan, factory, productivity, Edison, improvement, battery, saving, fire, natural, burn, central heating, fire, soil, forest, magnetics, heat, Alper Erözen, wave, science class, force, happiness, wood, motor, battery, light, computer, redbull, nuclear, robot, synergy, redbull (an energy drink), positive, tempo, Tesla, river, moon, study, nourish, football.

49 different words related to energy were generated by the $11^{\text {th }}$ grade students. 32 of these words are not included in the table and concept network, as they fell outside the specified cut-off points. The words were listed below the table. That is, the words uttered fewer than four times were excluded from the analysis. Considering $11^{\text {th }}$ grade students' words related to energy, 17 words were included in the analysis and the mostly articulated word was "electricity" ( $\mathrm{f}=19)$.

Table $4.12^{\text {th }}$ grade students' responses related to energy and their frequency values

\begin{tabular}{cccccc}
\hline Code & Response & $\mathrm{f}$ & Code & Response & $\mathrm{f}$ \\
\hline 1 & Potential & 28 & 11 & Productivity & 8 \\
2 & Kinetics & 24 & 12 & Wind & 7 \\
3 & Mechanics & 19 & 13 & Light & \\
4 & Heat & & 14 & Electricity & 6 \\
5 & Nuclear & 15 & 15 & Sun & \\
6 & Voice & 13 & 16 & Fire & \\
7 & Temperature & 12 & 17 & Source & 5 \\
8 & Bio-fuel & & 18 & Reserve & \\
9 & Oil & 10 & 19 & Protein & \\
10 & Water & & 20 & Others & 57 \\
\hline
\end{tabular}

Responses with frequencies of four and less than four are collected under the other option in the table. Responses to others are as following; chemical, renewable, natural gas, coal, wave, AKSA (energy company), battery, saving, internet, non-renewable, joule, fan, technology, practical, time, health, getting tired, radiator, fire, soil, redbull (an energy drink), life, mind, Edison, machine, natural, robot, Turkey, accumulator, clock, relax, Earth, wood, science class.

The $12^{\text {th }}$ grade students generated 53 different words related to energy. 34 of these words are not included in the table and concept network, as they fell outside the specified cut-off points. The words were listed below the table. That is, the words uttered fewer than four times were excluded from the analysis. Considering the $12^{\text {th }}$ grade students' words related to energy, 19 words were included in the analysis and the mostly articulated word was "fossil fuels" ( $\mathrm{f}=28)$. 


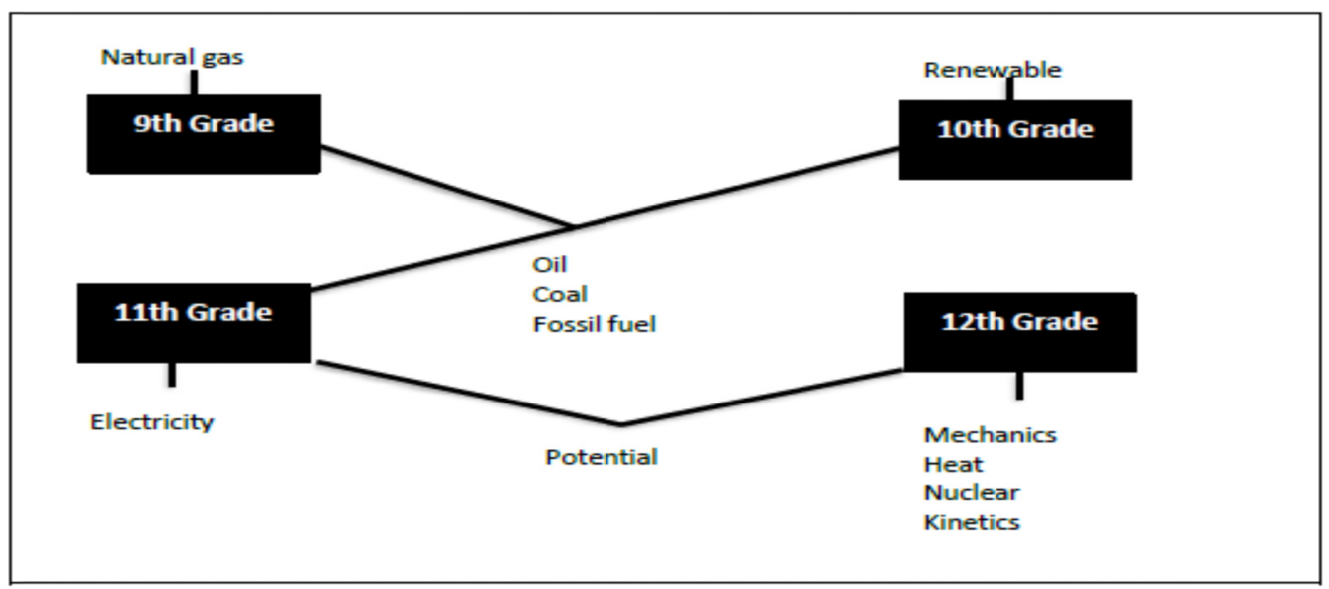

Figure 1. Concept network designed for cut-off points 15 and above

Figure 1, which displays the conceptual network of the words related to energy concept and the classes as a whole, indicates that there are 11 words in the conceptual network created with a cut-off point as 15 and higher. Three of these words were generated by the $9^{\text {th }}$ graders, the $10^{\text {th }}$ and the $11^{\text {th }}$ classes, one was generated by the $11^{\text {th }}$ and the $12^{\text {th }}$ classes, only one word was created by $9^{\text {th }}$ class, only one word was created by the $10^{\text {th }}$ class, only one word was formed by the $11^{\text {th }}$ class and four words were generated only by the $12^{\text {th }}$ class.

Considering at all grade levels, the words that have frequency of 15 at least, therefore given at the cut-off point as 15 and above suggest that students relate the concept of energy mainly to energy sources, which are oil, coal, fossil fuel, electricity, natural gas, edible, mechanical, thermal, nuclear and kinetics. Especially, the existence of more scientific words among the $12^{\text {th }}$ grades such as mechanics, kinetics and potential can be interpreted as differences in the developmental process of classes.

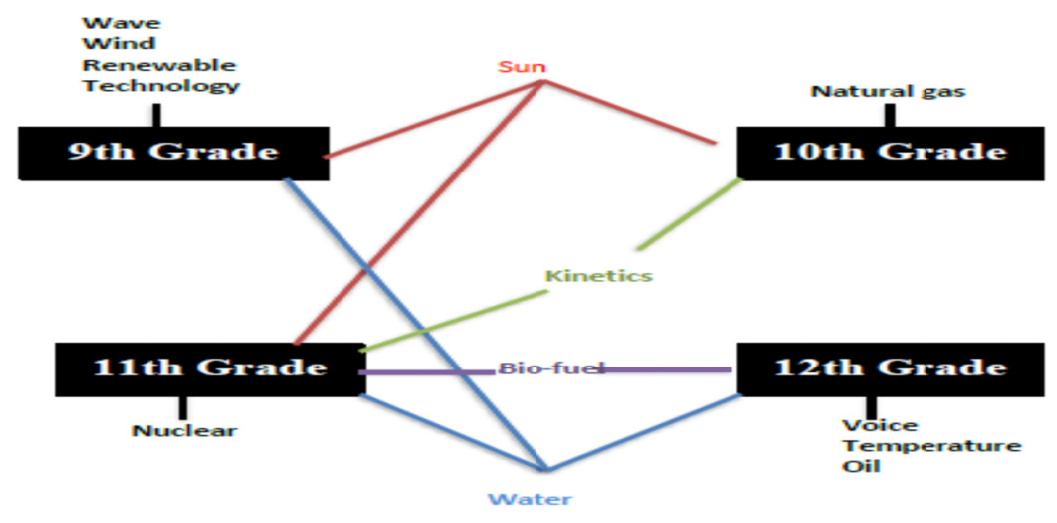

Figure 2. Concept network designed for cut-off points between 10-14

It is evident at Figure 2, where the class levels and the words produced for the energy concept were presented, there are 13 words in the concept network which is created by the cut-off points ranging between 10-14. Of all these words that were uttered for energy, one is for the $9^{\text {th }}$, the $10^{\text {th }}$ and the $11^{\text {th }}$ grades, one is for the $10^{\text {th }}$ and the $11^{\text {th }}$ grades, one is for the $11^{\text {th }}$ and the $12^{\text {th }}$ grades, one is for the $9^{\text {th }}, 11^{\text {th }}$ and $12^{\text {th }}$ grades. Moreover, four words were provided by the $9^{\text {th }}$ class, one word is stated by the $10^{\text {th }}$ grades, one word articulated by the $11^{\text {th }}$ grades, lastly, 3 words were stated by the $12^{\text {th }}$ grades. Considering at all grade levels, the words that have frequency of 10 at least and 14 at most, therefore given at the cut-off point between 10-14, it can be interpreted that students mostly related the concept of energy mainly to energy sources, which are sun, kinetics, bio-fuels, water, nuclear, wave, wind, renewable, technology, natural gas, voice, temperature and oil. In addition, considering the cut-off points, it can be 
deduced that there is a difference between the grades in terms of not providing the same words in different levels.

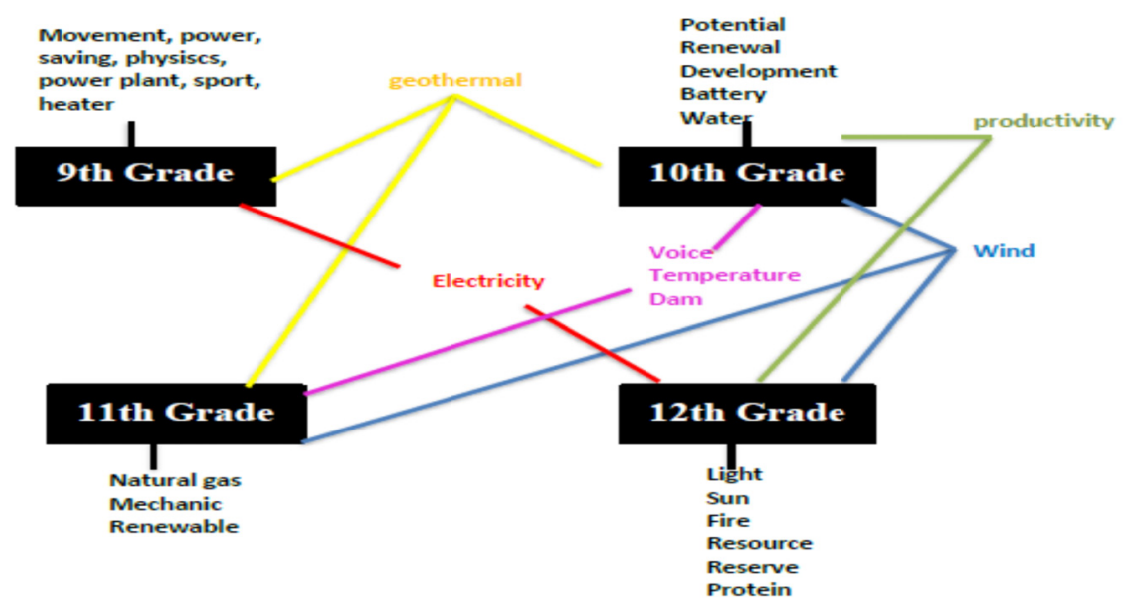

Figure 3. Concept network designed for cut-off points between 5-9

At Figure 3, which displays the grades and the words produced for the energy concept, there are 29 words in the concept network which is created by the cut-off points ranging between 5-9. Of all these words that were uttered for energy, one is for the $9^{\text {th }}$, the $10^{\text {th }}$ and the $11^{\text {th }}$ grades, one is for the $10^{\text {th }}$ and the $11^{\text {th }}$ grades, one is for the $9^{\text {th }}$ and the $12^{\text {th }}$ grades, one is for the $9^{\text {th }}$, the $12^{\text {th }}$ grades, and one is for the $10^{\text {th }}, 11^{\text {th }}$ and $12^{\text {th }}$ grades. Moreover, eight words were provided by $9^{\text {th }}$ class, five word is stated by $10^{\text {th }}$ grades, three word articulated by $11^{\text {th }}$ grades, lastly, six words were stated by $12^{\text {th }}$ grades. Considering at all grade levels, the words that have frequency of 5 at least and 9 at most, therefore given at the cut-off point between 5-9, the word are listed as following; geothermal, electricity, heat, voice, dam, productivity, wave, movement, saving, battery, sport, power, physics, power plant, heater, potential, renewal, development, water, natural gas, mechanics, renewable, light, sun, fire, reserve, protein. It is inferred that the words listed for 5-9 cut-off points are more specific than the other cut-off points.

\section{Discussion and Conclusion}

In the current study, 189 different words for energy concept were produced by high school students. Of all these words, 114 words were not included in the analysis because they have a frequency of four or less, while 75 words are included in the analysis.

Results show that among the words included in the analysis, the most common word in the $9^{\text {th }}$ graders is "oil" $(\mathrm{f}=30)$. This word is followed by "natural gas" $(\mathrm{f}=24)$, "coal" $(\mathrm{F}=23)$ and "heat" $(\mathrm{F}=19)$. The words and frequencies, produced by the $9^{\text {th }}$ classes, indicate that the concept of energy is usually associated with renewable and non-renewable energy sources, especially non-renewable energy sources. Furthermore, among all classes, the $9^{\text {th }}$ graders shared most of the words, leading to the inclusion of 21 words in the analysis.

Of all the words included in the analysis, the most common word in the $10^{\text {th }}$ graders is "fossil fuel" ( $\left.\mathrm{f}=24\right)$. This word is followed by "coal" ( $\mathrm{f}=19)$, "oil" ( $\mathrm{f}=16)$ and "renewable" ( $\mathrm{f}=16)$. The words and frequencies provided by the $10^{\text {th }}$ grades show that students generally relate the energy concept to energy concepts like the $9^{\text {th }}$ grade students do. The results revealed that the $10^{\text {th }}$ graders shared the fewest number of words among other classes, which are just 41 words.

The most commonly used word among the $11^{\text {th }}$ graders is "electricity" ( $\left.\mathrm{f}=19\right)$. "Coal" and "oil" ( $\left.\mathrm{f}=16\right)$ and "potential" ( $\mathrm{f}=15)$ follow that word in the analysis. Moreover, of all classes, the $11^{\text {th }}$ graders are the ones who shared the fewest words (17 words) to the word list that is included in the analysis. Among the words included in the analysis, the most common word in the $12^{\text {th }}$ grades is "potential" ( $\left.\mathrm{f}=28\right)$. This word is followed by "mechanics" $(\mathrm{f}=19)$, "heat" and "nuclear" ( $\mathrm{f}=15)$. Considering the words uttered by $12^{\text {th }}$ grades, it is understood that they approach the term "energy" more scientifically than the other classes. Besides, the $12^{\text {th }}$ grades students provided a large number of words ( 53 words) to the word list, which made up of the considerable part of word lists that were analyzed.

There is no significant difference between the grades in terms of quality and quantity. As the grades of students 
increased, the quality of their responses increased as well. The reasons to explain this difference is the content of the $10^{\text {th }}$ and $11^{\text {th }}$ grades curriculum and also the students' development in time. The findings of the current research suggest that the words produced for the concept of energy are largely consistent with the extant literature. However, there exists misconception in some words. It will be useful to conduct studies at various levels of students to overcome this misconception. The concept of energy, which falls within the field of many disciplines, should be conveyed by associating it with other disciplines. Making association has a great importance in teaching the concept of energy. Otherwise, occurrence of misconception is inevitable.

Energy is the most important element for the development or even maintenance of the country It is very important to transfer this consciousness to the next generations. It should be noted that if next generations do not recognize the importance of energy, they may have to face big problems in the future. It should be taken into account that the environmental problems that the human beings going through will affect each individual one by one. This point of view suggests that students should be educated regarding the concept of energy. Adopting the idea that the measures that students will take individually will create a snowball effect is really important. Because details that can be perceived as small and are not cared much can cause big social problems in total.

Renewable energy is another point to focus on when educating the students about the concept of energy. It should be emphasized that renewable energy is important for humanity and the future of humanity. Moreover, it is essential to recognize Turkey's renewable energy sources and the country's potential for renewable energy. For example, Turkey does not have oil and natural gas reserves, which are quite common in usage among the energy sources. A significant amount of them is imported, which in return leads to both foreign trade deficiency of the country and an external dependency. Energy produced by renewable energy sources across the country enable Turkey to solve these problems.

\section{Recommendation}

- According to the results of the research, the following recommendations can be made:

- Existing misconceptions should be eliminated by practicing meaning analysis tables, conceptual change texts, concept maps, concept cartoons, analogies and worksheets in order to make students internalize the concept of energy.

- Students should be encouraged to carry out research projects in their neighborhood to prevent misunderstandings related to the concept of energy in students' cognitive structures.

- In order to avoid misunderstandings related to the concept of energy in students' cognitive structures, a poster competition can be organized at the school and displayed to families and other students during the week of the Science Festival.

\section{References}

Akbulut, G. (2008). Küresel değişimler bağlamında dünya enerji kaynakları, sorunlar ve Türkiye. Sosyal Bilimler Dergisi/Journal of Social Sciences, 32(1), 117-137. Retrieved from http://eskidergi.cumhuriyet.edu.tr/makale/1688.pdf

Akova, İ. (2008). Yenilenebilir enerji kaynakları. Ankara: Nobel Yayın Dağıtım.

Aladăg, C., Tapur, T. \& Duran, Y. (2018). Coğrafya öğretmen adaylarının güneş enerjisi konusundaki algılarının belirlenmesi. Gelecek Vizyonlar Dergisi, 2(3), 17-27.

Amador Amador, B. L., Carbonero Rosales, S., \& Jarquin Cabrera, A. W. (2021). Word association technique to strengthen in EFL students' vocabulary acquisition (Unpublished Doctoral dissertation). Universidad Nacional Autónoma de Nicaragua.

Atılgan, İ. (2000). Türkiye'nin enerji potansiyeline bakış. Gazi Üniversitesi Mühendislik Mimarlık Fakültesi Dergisi, 15(1), 31-47. Retrieved from https://dergipark.org.tr/tr/download/article-file/76406

Ay, E., \& Tokcan, H. (2019). An investigation of prospective social studies teachers' cognitive structures regarding creative drama. International Education Studies, 12(5), 56-67. https://doi.org/10.5539/ies.v12n5p56

Aydın, F. F. (2010). Enerji tüketimi ve ekonomik büyüme. Erciyes Üniversitesi İktisadi ve İdari Bilimler Fakültesi Dergisi, 35, 317-340. Retrieved from https://dergipark.org.tr/tr/download/article-file/66570

Bahar, M., \& Hansell, M. H. (2000). The relationship between some psychological factors and their effect on the performance of grid questions and word association tests. Educational Psychology, 20(3), 349-364. https://doi.org/10.1080/713663739 
Bahar, M., \& Özatlı, S. (2003). Kelime ilişkilendirme test yöntemi ile lise 1. sınıf öğrencilerinin canlıların temel bileşenleri konusundaki bilişsel yapılarının araştırılması. BAÜ Fen Bilimleri Enstitüsü Dergisi, 5(2), 75-85. Retrieved from https://dergipark.org.tr/tr/pub/baunfbed/issue/24783/261831

Bahar, M., Johnstone, A. H., \& Sutcliffe, R. G. (1999). Investigation of students' cognitive structure in elementary genetics through word association tests. Journal of Biological Education, 33(3), 134-141. https://doi.org/10.1080/00219266.1999.9655653

Bilginoğlu, M. A. (1991). Gelişmekte olan ülkelerde enerji sorunu ve alternatif enerji politikaları. Erciyes $\begin{array}{llllll}\text { Üniversitesi } & \text { I.I.B.F. } & \text { Dergisi, } & 9, & \text { 122-147. } & \text { Retrieved }\end{array}$ https://dergipark.org.tr/tr/pub/erciyesiibd/issue/38185/449081

Cachapuz, A. F. C., \& Maskill, R. (1987). Detecting changes with learning in the organisation of knowledge: use of word association tests to follow the learning of collision theory. International Journal of Science Education, 9, 491-504. https://doi.org/10.1080/0950069870090407

Cardellini, L., \& Bahar, M. (2000). Monitoring the learning of chemistry through word association tests. Australian Chemistry Resource Book, 19, 59-69.

Çifçi, S. (2009). Kelime çağrışımlarının cinsiyet değişkenine göre gösterdiği temel nitelikler üzerine bir deneme. Turkish Studies, 4(3), 633-654. https://doi.org/10.7827/TurkishStudies.697

Çolak, K., Kaymakçı, S., \& Akpınar, M. (2012). Sosyal bilgiler öğretim programında, ders kitaplarında ve öğretmen adaylarının görüşlerinde yenilenebilir enerji kaynaklarının yeri. Eğitim Bilimleri Dergisi, 4, 59-76. https://doi.org/10.15285/ebd.88939

Çukurçayır, M. A., \& Sağır, H. (2008). Enerji sorunu, çevre ve alternatif enerji kaynakları. Selçuk Üniversitesi Sosyal Bilimler Enstitüsü Dergisi, 20, 257-278.

Deveci, H., Çengelci Köse, T., \& Gürdoğan Bayır, Ö. (2014). Öğretmen adaylarının sosyal bilimler ve sosyal bilgiler kavramlarına ilişsin bilişsel yapıları: kelime ilişkilendirme testi uygulaması. Adıyaman Üniversitesi Sosyal Bilimler Enstitüsü Dergisi, 7(16), 101-124. https://doi.org/10.14520/adyusbd.732

Dikmenli, Y., Öztürk Demirbaş, Ç., \& Gafa, İ. (2019). Öğretim elemanlarının Türkiye'de nükleer enerjiye yönelik görüşleri. Gazi Eğitim Bilimleri Dergisi, 5, 254-272.

Doğanay, H., \& Coşkun, O. (2018). Enerji kaynakları (3. Basım). Ankara: Pegem Akademi Yayınevi.

Dönmez Usta, N., Karslı, F., \& Durukan, Ü. G. (2016). Bilgisayar destekli öğretim materyalinin öğretmen adaylarının yenilenebilir enerji ve kaynaklarını öğrenmelerine etkisi. Mersin Üniversitesi Eğitim Fakültesi Dergisi, 12(1), 196-210. https://doi.org/10.17860/efd.70389

Ercan. F., Taşdere, A., \& Ercan, N. (2010). Kelime ilişkilendirme testi aracılığıyla bilişsel yapının ve kavramsal değişimin gözlenmesi. Türk Fen Eğitimi Dergisi, 2, 136-154.

Geçit, Y., \& Yangın, S. (2012). Öğretmen adaylarının hidroelektrik santralleri konusundaki bilişsel anlayışları. Pegem Ĕgitim ve Öğretim Dergisi, 2(4), 29-39. https://doi.org/10.14527/C2S4M3

Gough, H. G. (1976). Studying creativity by means of word association tests. Journal of Applied Psychology, 61(3), 348. https://doi.org/10.1037/0021-9010.61.3.348

Haskök A. Ş. (2005). Türkiye'nin mevcut enerji kaynaklarının durum değerlendirilmesi (Yüksek Lisans tezi). Retrieved from https://tez.yok.gov.tr

Işıklı, M., Taşdere, A., \& Göz, N. L. (2011). Kelime ilişkilendirme testi aracılığıyla öğretmen adaylarının Atatürk ilkelerine yönelik bilişsel yapılarının incelenmesi. Uşak Üniversitesi Sosyal Bilimler Dergisi, 4(1), 50-72.

Johnstone, A. H., \& Moynihan, T. F. (1985). The relationship between performances in word association tests and achievement in chemistry. European Journal of Science Education, 7, 57-66. https://doi.org/10.1080/0140528850070106

Kantemir, S. (2003). Nükleer enerji teknolojileri ve Türkiye'deki geleceği (Yüksek Lisans tezi). Retrieved from https://tez.yok.gov.tr

Kar, E. B. (2021). Investigation of students' cognitive structures and changes in understanding on the topic of "inventions" using word association tests. European Journal of Education Studies, 8(1), 360-372.

Karabulut, Y. (2000). Türkiye enerji kaynakları. Ankara: Ankara Üniversitesi Basımevi.

Karasar, N. (2014). Bilimsel araştırma yöntemi, kavramlar-ilkeler-teknikler. Ankara: Nobel Yayın Dağıtım. 
Kaya, B., \& Akış, A. (2015). Coğrafya öğrencilerinin "hava” kavramıyla ilgili bilişsel yapılarının kelime ilişkilendirme testi ile belirlenmesi. Turkish Studies, 10(7), 557-574.

Kaygusuz, K. (1999). Utilization of solar energy and waste heat. Energy Sources, 21, 595-610. https://doi.org/10.1080/00908319950014542

Keleş, R., \& Hamamc1, C. (2002). Çevrebilim. Ankara: İmge Kitabevi.

Kılıç Avan, Ş., \& Kalenderoğlu, İ. (2018). Yabancı öğrencilerin kelime ilişkilendirme testi ile Türk kültürü konusundaki bilişsel yapılarının belirlenmesi, 21. Yüzyılda Eğitim ve Toplum, 7, 51-64.

Koç, E., \& Kaya, K. (2015). Enerji kaynaklar1-yenilenebilir enerji durumu. Mühendis ve Makina, 56(668), $36-47$.

Kurtaslan, Z., Aydın, B., \& Özer, B. (2018). Kelime ilişkilendirme testi aracıllı̆ı̆yla ortaokul ve lise öğrencilerinin "müzik öğretmeni" kavramına yönelik bilişsel yapılarının belirlenmesi. Ekev Akademi Dergisi, 74, 375-390.

Önder, İ. (2001). Yenidünya düzeni ve enerji politikaları. Türkiye Üçüncü Enerji Sempozyumu Bildirileri, 8-18.

Pamir, A. N. (2003). Dünyada ve Türkiye'de enerji, Türkiye'nin enerji kaynakları ve enerji politikaları. Metalurji Dergisi, 134, 73-100.

Şen, Z. (2009). Temiz enerji kaynakları ve modelleme ilkeleri. İstanbul: Su Vakfı Yayınları.

Şimsek, M. (2013). Sosyal bilgiler öğretmen adaylarının coğrafi bilgi sistemleri (CBS) konusundaki bilişsel yapılarının ve alternatif kavramlarının kelime ilişkilendirmesi testi ile belirlenmesi. Researcher: Social Science Studies, 1(1), 64-75.

Tokcan, H. (2017). Determining the Turkish World Perceptions of Candidate Social Studies Teachers through Word Association Test. Universal Journal of Educational Research, 5(8), 1386-1395. https://doi.org/10.13189/ujer.2017.050812

Tokcan, H., \& Topkaya, Y. (2018). Prospectıve teachers' perceptions about concept of middle east through word association test. MANAS Journal of Social Studies, 7(2), 45-57.

Tokcan, H., \& Yiter, E. (2017). 5. sınıf öğrencilerinin doğal afetlere ilişkin bilişsel yapılarının kelime ilişkilendirme testi (kit) aracılı̆̆ı̆la incelenmesi. Ahi Evran Üniversitesi Kırşehir Eğitim Fakültesi Dergisi, 18(1), 115-129.

Türk Dil Kurumu. (2005). Türkçe sözlük (10. Baskı). Ankara: Türk Dil Kurumu Yayınları.

Ülgen, K., \& Hepbaşl1, A. (2002). Prediction of solar radiation parameters through clearness index for İzmir. Energy Sources, 24, 773-785.

Uslu, K. (2004). Avrupa Birliğinde enerji ve politikaları. Marmara Üniversitesi I.I.I.B.F. Dergisi, 19(1), 155-172.

Üstün, A. K., Apaydın, M., Başaran Filik, Ü., \& Kurban M. (2009). Kyoto protokolü kapsamında Türkiye'nin yenilenebilir enerji politikalarına genel bir bakış. Yenilenebilir Enerji Kaynakları Sempozyumun Dergisi, 23-28.

Yel, Ü., \& Çetin, T. (2020). Investigation of secondary school students' perceptions of energy through vocabulary association test. XI. IMCOFE 20 (July 07-09 2020, St. Petersburg/Russia) Proceeding Book (pp. 208-218).

Yel, Ü., Çetin, T., \& İnel, Y. (2019). Ortaokul öğrencilerinin kültür kavramına ilişkin algılarının kelime ilişkilendirme testi aracılığıyla incelenmesi, IV. Uluslararası Sosyal Bilimler Araştırmaları Kongresi Bildiriler Kitabl, 400-412.

Yıldırım, A., \& Şimşek, H. (2013). Sosyal bilimlerde nitel araştırma yöntemleri (11. baskı). Ankara: Seçkin.

Yıldırım, M., \& Örnek, İ. (2007). Enerjide son seçim: Nükleer enerji. Gaziantep University Journal of Social Sciences, 6(1), 32-44. Retrieved from https://dergipark.org.tr/tr/pub/jss/issue/24259/257149

Yılmaz, İ., İlbaş, M., \& Su, Ş. (2003). Türkiye rüzgâr enerjisi potansiyelinin değerlendirilmesi. Yeni ve Yenilenebilir Enerji Kaynaklarl Sempozyumu Bildirileri, 399-401. 


\section{Copyrights}

Copyright for this article is retained by the author(s), with first publication rights granted to the journal.

This is an open-access article distributed under the terms and conditions of the Creative Commons Attribution license (http://creativecommons.org/licenses/by/4.0/). 